\title{
Facultative endosymbionts of aphid populations from coastal dunes of the North Sea
}

\author{
Eduardo de la Peña ${ }^{1,2, *}$, Viki Vandomme ${ }^{1,3}$ \& Enric Frago ${ }^{4}$
}

\author{
1 Ghent University, Department of Biology, Terrestrial Ecology Unit, K.L. Ledeganckstraat 35, 9000 Gent, Belgium \\ 2 Instituto de Hortofruticultura Subtropical y Mediterránea "La Mayora", Universidad de Málaga - Consejo Superior de \\ Investigaciones Científicas, E-29750 Algarrobo-Costa (Málaga), Spain \\ 3 Royal Belgian Institute of Natural Sciences, Vautierstraat 29, 1000 Brussels, Belgium \\ 4 Laboratory of Entomology, Wageningen University, P.O. Box 8031, 6700 EH Wageningen, the Netherlands \\ * Corresponding author: eduardo.delapena@ugent.be
}

\begin{abstract}
Aphids establish symbiotic associations with a diverse assemblage of mutualistic bacteria. Some of them are not required for the host's survival but still have a crucial impact on the biology and ecology of their host. Facultative symbionts may modify important host-life-history traits and affect the interactions of aphids with other members of the community. So far several species of aphid have been reported to occur in coastal dunes. Given the extreme environmental conditions of this type of habitat and the wide distribution along the European coast of some aphid species, these aphids would be expected to show variation in their facultative endosymbionts. However, there is currently no information available for these species. To address this question, we collected specimens from different populations of aphids (i.e. Schizaphis rufula, Laingia psammae and Rhopalosiphum padi) associated with the dune grass Ammophila arenaria in several locations of the North and the Irish Sea. By means of specific diagnostic PCR's we checked for the presence of facultative bacterial endosymbionts in these populations. Results of this explorative assessment showed variation in the endosymbiont community according to species and location. All populations sampled along the North Sea coast were associated with the facultative endosymbiont Serratia symbiotica. Hamiltonella defensa was only detected in some specimens coming from the population in Het Zwin, Belgium. Regiella insecticola and the $\gamma$-protobacteria X-type were only found associated with the population of Schizaphis rufula in De Panne, Belgium. Although further experiments are necessary to characterize the nature of these symbiotic relationships, our correlation analyses showed a significant co-occurrence of $S$. symbiotica with $H$. defensa and $R$. insecticola with X-type protobacteria suggesting reciprocal regulatory functions. No significant correlation was detected between the number of mummies (i.e. carcasses of aphids parasitized by wasps) and the occurrence of bacterial symbionts. The potential role of these symbionts in coastal dune ecosystems is discussed.
\end{abstract}

KEY WORDS: wasps, parasitoids, heat shock, specific primers, top-down, bottom-up control

\section{INTRODUCTION}

Aphids are one of the most common insect groups studied for symbiotic associations (Oliver et al., 2010; MorAN et al., 2008). Aphids engage in symbiotic associations with a diverse assemblage of heritable bacteria. In addition to the obligate endosymbiont Buchnera aphidicola, aphids may carry one or more facultative bacterial symbionts. Although these symbionts are not required for the survival of the aphid, they may transfer beneficial features to their hosts such as increased resistance against natural enemies and pathogens, protection from heat shocks, and more importantly influence survival and fitness on specific host plants (OLIVER et al., 2010; LEONARDO \& MONDOR, 2006).

Several aphid species have been reported to occur along the Western European Atlantic coast and the North Sea, including Schizaphis rufula (WALKER, 1849), Laingia psammae (THEOBALD, 1922), Metapolophium sabiahe (PRIOR, 1976) and Rhopalosiphum padi (1758) (BRÖRING \& 
NiEDRINGHAUS, 1989; VANDEGEHUCHTE et al., 2010). These species are usually found on Ammophila arenaria (L.) Link but also on other dune grasses thriving in pioneer dunes e.g. Elymus farctus, Festuca rubra and Leymus arenaria. From laboratory observations we know that these aphid species reproduce freely on young Ammophila arenaria shoots and spikes (VANDEGEHUCHTE etal., 2009; VANDEGEHUCHTE et al., 2010) but the factors underlying their ecology and population dynamics in the field remain relatively unexplored. Aphid populations colonizing coastal dunes do not commonly reach high densities as they are controlled either by natural enemies or by constitutive and induced plant defenses regulated by plant mutualists such as fungal endophytes (VANDEGEHUCHTE et al., 2013; DE LA PEÑA et al., 2006). Moreover, for some aphid species the endosymbiont community plays an important role in defining the host-plant range and the ability to exploit certain plant species (LUKASIC et al., 2013, MORAN et al., 2008). Therefore, to understand aphid-plant interactions in coastal dunes the endosymbiont community in dune aphids needs to be characterized.

Coastal dunes are extreme environments, where both plant and animal species have to cope with several environmental stresses such as sand accretion, salt spray, extreme temperature variability, wind, etc (MAUN 2009). In addition to these abiotic factors, aphids have to deal with the host-plant defences, other herbivore competitors exploiting the same host-plants, and their natural enemies. Mutualism with facultative (i.e. non-essential) heritable bacteria may influence the biology of these insects, and can have major (positive and negative) effects on the host's fitness (MORAN et al., 2008). Facultative symbionts of aphids can confer protection against insect parasitoids and also

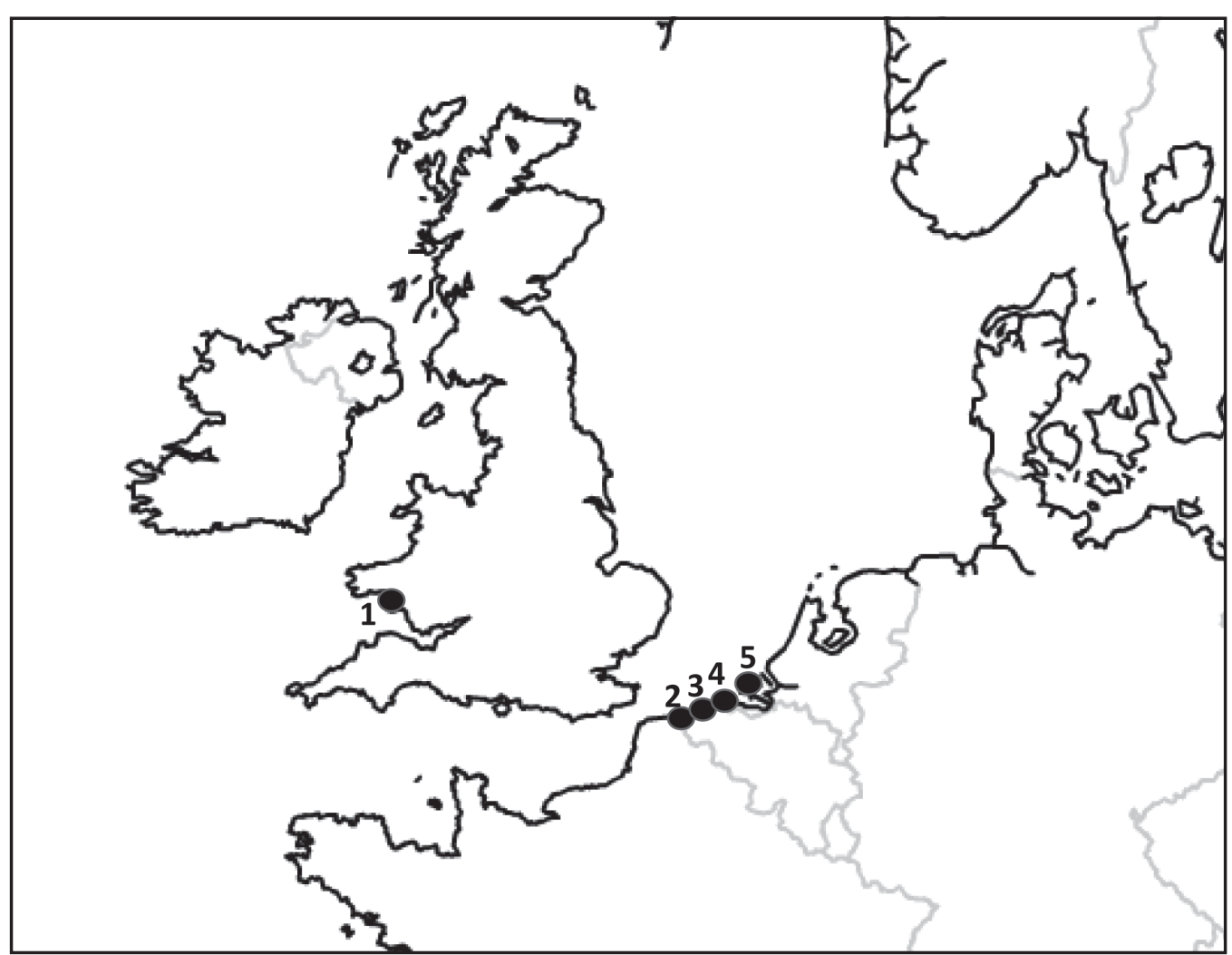

Fig. 1. - The five geographic locations sampled, and the aphid species found, in this study. 1. Ynyslas (Wales, UK): Schizaphis rufula. 2. Westhoek (Belgium): S. rufula and Rhopalosiphum padi. 3. Ter Yde: S. rufula. 4. Sluis-Het Zwin (the Netherlands): S. rufula and Laingia psammae. 5. Duinnoord (the Netherlands): S. rufula. 
increase resistance to extreme temperatures. Recent research suggests that in the pea aphid, Acyrthosiphon pisum, the population structure of some species of facultative symbionts is mostly influenced by climate. In particular, symbiont species that confer resistance to heat shocks have been found to be commonly associated with aphids from arid regions (HENRY et al., 2013).

With such a priori knowledge it is not farfetched to assume that dune aphids rely on such mutualistic interactions to better survive and we report here the first records on dune aphidendosymbiotic bacteria associations in several locations of the Atlantic and North Sea coast in Western Europe.

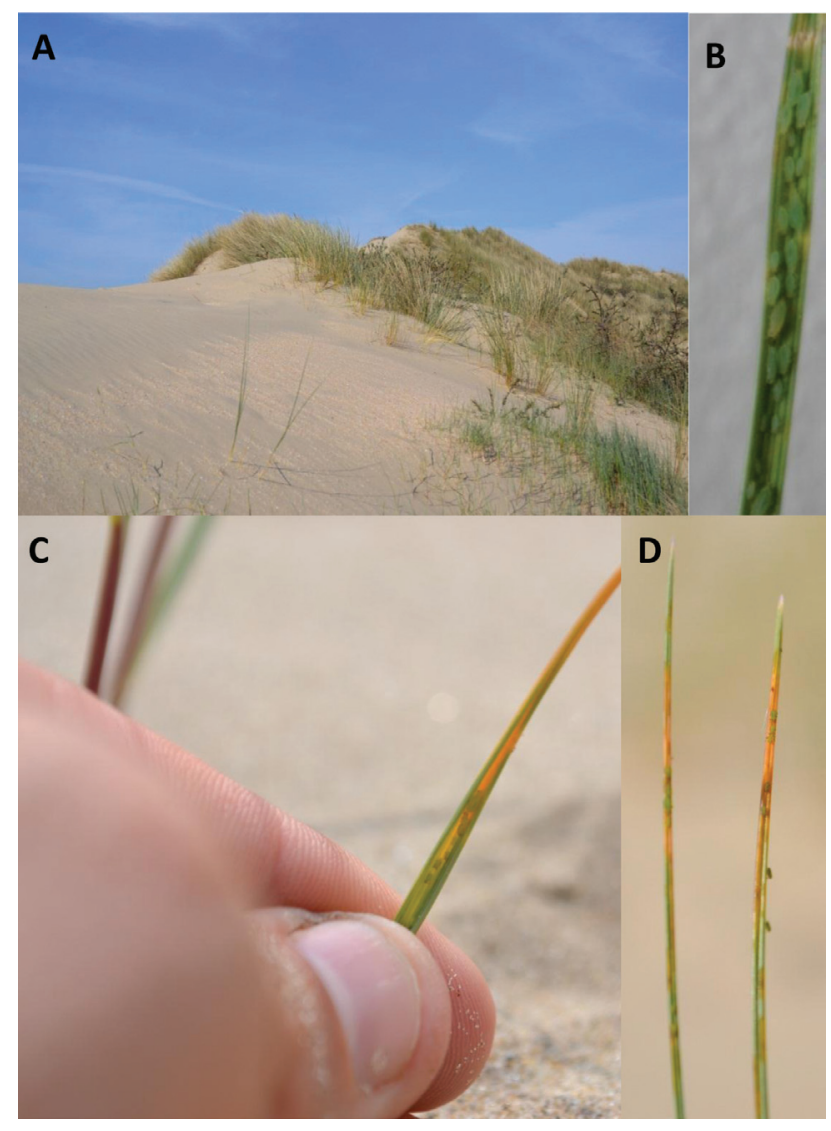

Fig. 2. - A. Foredunes with vigorous Ammophila arenaria where the different populations of aphids were collected. B. Infestation of marram leaves by the aphid Schizaphis rufula. C-D. Symptoms of aphid multiplication: yellowing of leaf tips.

\section{MATERIAL AND METHODS}

\section{Sampling surveys and establishment of cultures of aphid isolates}

In total, five locations with active dune systems dominated by $A$. arenaria were sampled along the coast of the North Sea and the Irish Sea (Fig. 1). The first sampling survey took place in June 2011. In the field, plants were visually inspected to detect aphid populations feeding on $A$. arenaria shoots (Figs 2-3). Once aphids were detected, they were manually collected and transferred to an eppendorf tube filled with $100 \%$ ethanol. From each site we collected aphids from at least four different plants. During this first sampling survey individuals of the species $S$. rufula were retrieved from De Panne, Ter Yde and Het Zwin. In De Panne (Belgium), individuals of the species $R$. padi were also detected and sampled. Once in the lab, the identity of 10-15 aphids from each location was double-checked and this bulk sample was further used for DNA extraction.

Since the preliminary assessment based on bulk samples revealed the presence of bacterial endosymbionts, in a second sampling survey, aphids were individually screened for symbiont infection to assess the frequency of infection by different endosymbiotic bacteria within a site. In October 2011, the same populations were revisited and aphids were taken to the laboratory alive in order to establish cultures of the different isolates. Also in October 2011, parasitoid impact was assessed by counting the number of mummies (i.e. carcasses of aphids parasitized by parasitoid wasps) and healthy aphids on the surveyed plants and locations. Once in the lab, leaves infested with aphids were transferred to $A$. arenaria seedlings that had been previously prepared as in DE LA PEÑA et al. (2010). To ensure aphids were kept in conditions as natural as possible, we reared them in sympatric $A$. arenaria plants. In our second survey, we did not detect $R$. padi as in the preliminary survey, and instead we detected L. psammae (Fig. 3) in plants from the location sampled in the Netherlands. From each site and species, we established between ten to 
fifteen aphid lines (i.e. from a single female), which we kept in the laboratory under long photoperiod (16/8h light/dark regime) to ensure continuous asexual reproduction. In order to assess the degree of incidence of endosymbionts per species and population we checked for the presence of the different endosymbionts in 10 aphid-lines per population.

With the data for S. rufula from the second sampling survey, a Spearman correlation analysis was conducted to infer patterns in the simultaneous occurrence of the different facultative endosymbionts and the number of mummies (i.e. carcasses of aphids that have been parasitized by wasps) detected in the field.

\section{Extraction of DNA and PCR for molecular identifications}

Genomic DNA was extracted using the NucleoSpin ${ }^{\circledR}$ Tissue Kit (Macherey-Nagel). The facultative endosymbiont communities of
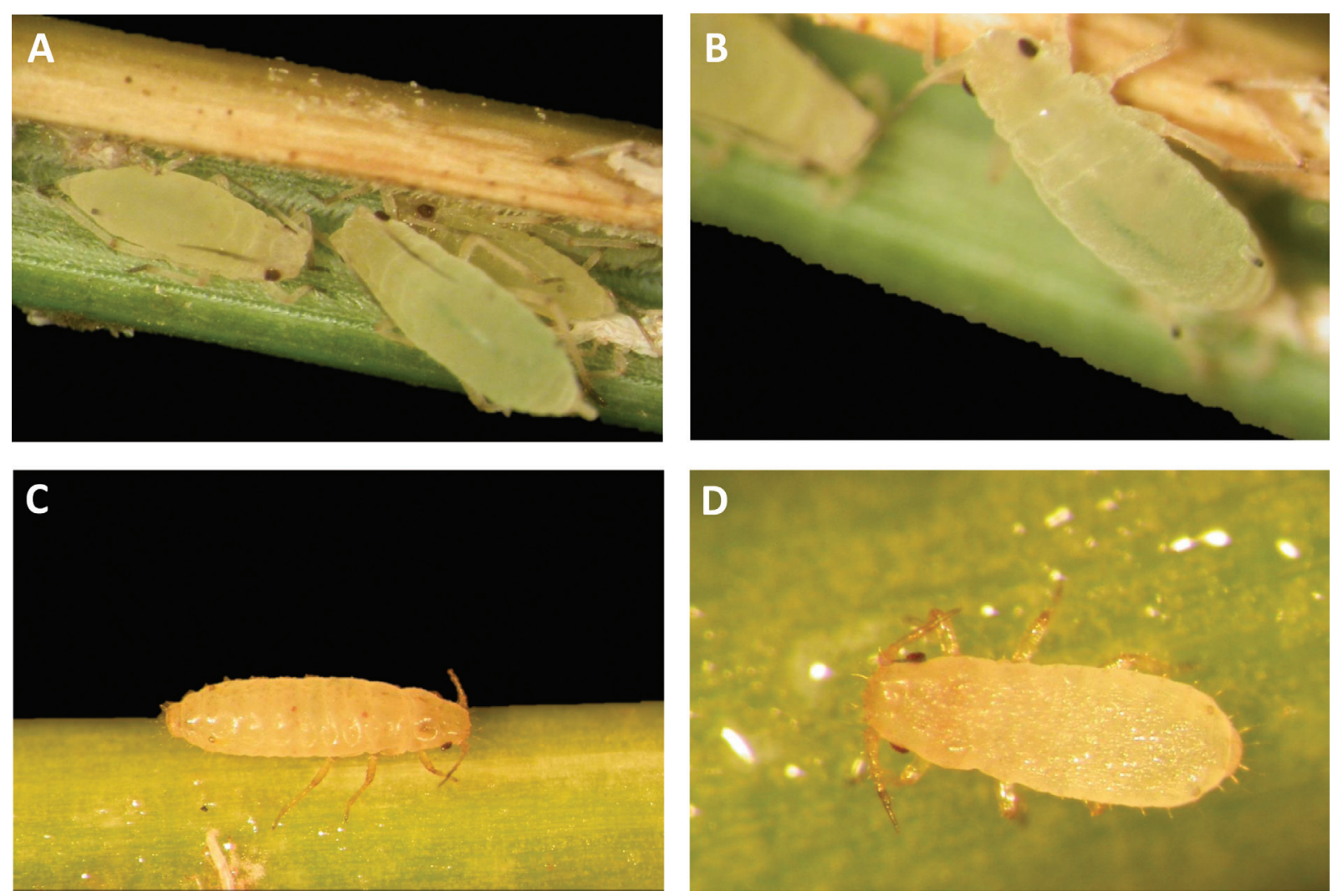

Fig. 3. - Schizaphis rufula (A, B) and Laingia psammae (C, D) on leaves of Ammophila arenaria. 


\section{TABLE 1}

Specific primers and PCR conditions for diagnostic symbiont detection. From MCLEAN et al., 2010 and FERRARI et al., 2011.

\begin{tabular}{|c|c|c|c|}
\hline Symbiont species & Forward primer & Reverse primer & PCR programm \\
\hline Hamiltonella defense & $\begin{array}{l}\text { 10F } \\
\text { 5'- } \\
\text { AGTTTGATCATGGCTCA- } \\
\text { GATT-3, } \\
\end{array}$ & $\begin{array}{l}\text { T419R } \\
\text { 5'- } \\
\text { AAATGGTATTCGCATT- } \\
\text { TATCG-3' }\end{array}$ & 1 \\
\hline Regiella insecticola & $10 \mathrm{~F}$ & $\begin{array}{l}\text { U443R } \\
5 \text { '- } \\
\text { GGTAACGTCAATCGATAAG- } \\
\text { CA-3' } \\
\end{array}$ & 1 \\
\hline Serratia symbiotica & $10 \mathrm{~F}$ & $\begin{array}{l}\text { R443R } \\
\text { 5'- } \\
\text { CTTCTGCGAGTAACGTCAA- } \\
\text { TG-3' } \\
\end{array}$ & 1 \\
\hline X-Type & $10 \mathrm{~F}$ & $\begin{array}{l}\text { X420R } \\
\text { 5'- } \\
\text { GCAACACTCTTTGCAT- } \\
\text { TGCT-3' } \\
\end{array}$ & 1 \\
\hline Rickettsia & $\begin{array}{l}\text { 16SA1 } \\
\text { 5'- } \\
\text { AGAGTTTGATCMTGGCT- } \\
\text { CAG-3' }\end{array}$ & $\begin{array}{l}\text { Rick16SR } \\
\text { 5'- } \\
\text { TTTGAAAGCAATTCCGAG- } \\
\text { GT-3' }\end{array}$ & 1 \\
\hline Spiroplasma & $10 \mathrm{~F}$ & $\begin{array}{l}\text { TKSSsp } \\
\text { 5'- } \\
\text { ATCATCAACCCTGCCTTT-3' }\end{array}$ & 2 \\
\hline
\end{tabular}

Cycling conditions:

Programm 1: $94^{\circ} \mathrm{C} 2 \mathrm{~min}, 10$ cycles of $\left(94^{\circ} \mathrm{C} 1 \mathrm{~min}, 65^{\circ} \mathrm{Cà} 55^{\circ} \mathrm{C}\right.$ in $1{ }^{\circ} \mathrm{C}$ steps each cycle $\left.1 \mathrm{~min}, 72^{\circ} \mathrm{C} 2 \mathrm{~min}\right), 25$ cycles of $\left(94^{\circ} \mathrm{C} 1 \mathrm{~min}, 55^{\circ} \mathrm{C} 1 \mathrm{~min}, 72^{\circ} \mathrm{C} 2 \mathrm{~min}\right), 72^{\circ} \mathrm{C} 6 \mathrm{~min}$.

Programm 2: $94^{\circ} \mathrm{C} 2 \mathrm{~min}, 35$ cycles of $\left(94^{\circ} \mathrm{C} 1 \mathrm{~min}, 54^{\circ} \mathrm{C} 1 \mathrm{~min}, 72^{\circ} \mathrm{C} 2 \mathrm{~min}\right), 72^{\circ} \mathrm{C} 6 \mathrm{~min}$.

of $30 \mathrm{~s}$ at $94^{\circ} \mathrm{C}, 30 \mathrm{~s}$ at $\mathrm{Ta}(\gamma$-Proteobacteria $50^{\circ} \mathrm{C}$, Hamiltonella defensa $57^{\circ} \mathrm{C}$, Regiella insecticola, Serratia symbiotica $57^{\circ} \mathrm{C}$, X-type $57^{\circ} \mathrm{C}$, Rickettsia $45^{\circ} \mathrm{C}$, Spiroplasma $45^{\circ} \mathrm{C}$ ) and $1 \mathrm{~min}$ at $72^{\circ} \mathrm{C}$; a final step at $72{ }^{\circ} \mathrm{C}$ for $10 \mathrm{~min}$ was used to complete primer extension. PCR products were visualized after electrophoresis on a $1.2 \%$ agarose gel stained with GelRed. Since some PCR reactions produced faint bands, all PCR reactions were repeated twice to discard potential false positives. Furthermore, some of the PCR products were sequenced to confirm their identity based on sequence homologies (from GenBank) (BENSON et al., 2013). For this purpose, PCR products were purified using Exonuclease I and the purification kit FastAP ${ }^{\mathrm{TM}}$ (Fermentas). The purified PCR products were sequenced on both strands by Macrogen (Seoul, Korea) using the PCR primers.

\section{RESULTS}

The results of the assessment of the aphid populations collected during the sampling surveys showed that facultative endosymbionts are common and widespread in aphid populations occurring in coastal dunes (Table 2). PCR 
TABLE 2

Overview of endosymbionts in Schizaphis rufula, Rhopalosiphum padi and Laingia psammae based on the results of PCR amplifications using specific primers and posterior confirmation through sequence blasting.

\begin{tabular}{|llcccccc|}
\hline Species & Location & $\begin{array}{c}\text { Hamiltonella } \\
\text { defensa }\end{array}$ & Regiella & Type-X & $\begin{array}{c}\text { Serratia } \\
\text { symbiotica }\end{array}$ & Rickettsia & Spiroplasma \\
\hline S. rufula & Duin-Noord, Netherlands & No & No & No & Yes & No & No \\
S. rufula & Belgium, Het Zwin & Yes & No & No & Yes & No & No \\
S. rufula & Belgium, Ter Yde & No & No & No & Yes & No & No \\
S. rufula & Belgium, De Panne & No & Yes & Yes & Yes & No & No \\
S. rufula & Wales (UK), Ynyslas & No & No & No & No & No & No \\
R. padi & Belgium, De Panne & No & No & No & Yes & No & No \\
L. psammae & Belgium, De Panne & No & No & No & Yes & No & No \\
\hline
\end{tabular}

amplifications using specific primers for H. defensa yielded positive results (i.e. with an amplification band of $c a .490 \mathrm{bp}$ ) in one population, i.e. Het Zwin (the Netherlands). Serratia symbiotica was detected in all specimens tested except for the population of $S$. rufula from Ynyslas (Wales). The population of $R$. padi was found to be only associated with $S$. symbiotica. In all cases amplification bands had a size of $c a$. 890bp.

In the second assessment, using 10 aphid-lines, a different pattern in the results was observed (Fig. 4). Again, only the $S$. rufula population from Het Zwin was infected with $H$. defensa. Serratia symbiotica was once more the most common facultative endosymbiont although this time, the bacterium was not detected in specimens of $S$. rufula from Ter Yde. In this second study, we also detected $R$. insecticola and the $\gamma$-protobacteria $\mathrm{X}$-type in some specimens from the population in De Panne, yielding amplification bands near $470 \mathrm{bp}$ and $450 \mathrm{bp}$ respectively.

The identity of some of the positive samples was further confirmed by sequencing the PCR products and DNA blasting (BENSON et al., 2013). These sequences are available in GenBank and correspond with accession numbers KJ943256KJ943268.
The Spearman correlation analysis (Table 3) showed a significant co-occurrence of $S$. symbiotica with $H$. defensa, and $R$. insecticola with the endosymbiont X-type. The incidence of mummies in the field was not correlated with any of the endosymbionts detected.

\section{DISCUSSION}

By means of diagnostic PCRs we assessed the occurrence of facultative endosymbionts in different species and populations of aphids from coastal dunes. The results of this first assessment not only show that facultative endosymbionts are common elements in these aphids, but also showed variation in the endosymbiont community according to species and location. All populations, except S. rufula from Wales, were associated with facultative endosymbionts and by combining the results of the two sampling surveys, four different taxa of facultative endosymbionts were detected: $H$. defensa, S. symbiotica, R. insecticola and the $\gamma$-protobacteria X-type. Based on a relatively small sample (i.e. 10 aphid-lines per population/ species) we have shown that even within a population, there may be abundant variation in the occurrence of facultative endosymbionts; specimens coming from different A arenaria 


\section{TABLE 3}

Spearman coefficients for the correlation between facultative endosymbionts (i.e. Hamiltonella defensa, Serratia symbiotica) and the number of mummies observed in Schizaphis rufula.

\begin{tabular}{|l|c|c|c|c|c|}
\hline & H. defensa & S. symbiotica & R. insecticola & X-type & Mummies \\
\hline \multirow{2}{*}{ H. defensa } & & $\mathbf{0 . 6 1}$ & -0.05 & -0.05 & 0.14 \\
& & $<\mathbf{0 . 0 0 0 1}$ & 0.74 & 0.74 & 0.35 \\
\hline \multirow{2}{*}{ S. symbiotica } & $\mathbf{0 . 6 1}$ & & -0.08 & -0.08 & 0.08 \\
& $<\mathbf{0 . 0 0 0 1}$ & & 0.59 & 0.59 & 0.62 \\
\hline \multirow{2}{*}{ Regiella insecticola } & -0.05 & -0.08 & & $\mathbf{0 . 9 9}$ & 0.21 \\
\hline \multirow{2}{*}{ X-type } & 0.74 & 0.59 & & $<\mathbf{0 . 0 0 0 1}$ & 0.18 \\
\hline \multirow{2}{*}{ Mummies } & -0.05 & -0.08 & $\mathbf{0 . 9 9}$ & & 0.21 \\
& 0.74 & 0.59 & $<\mathbf{0 . 0 0 0 1}$ & & 0.18 \\
\hline
\end{tabular}

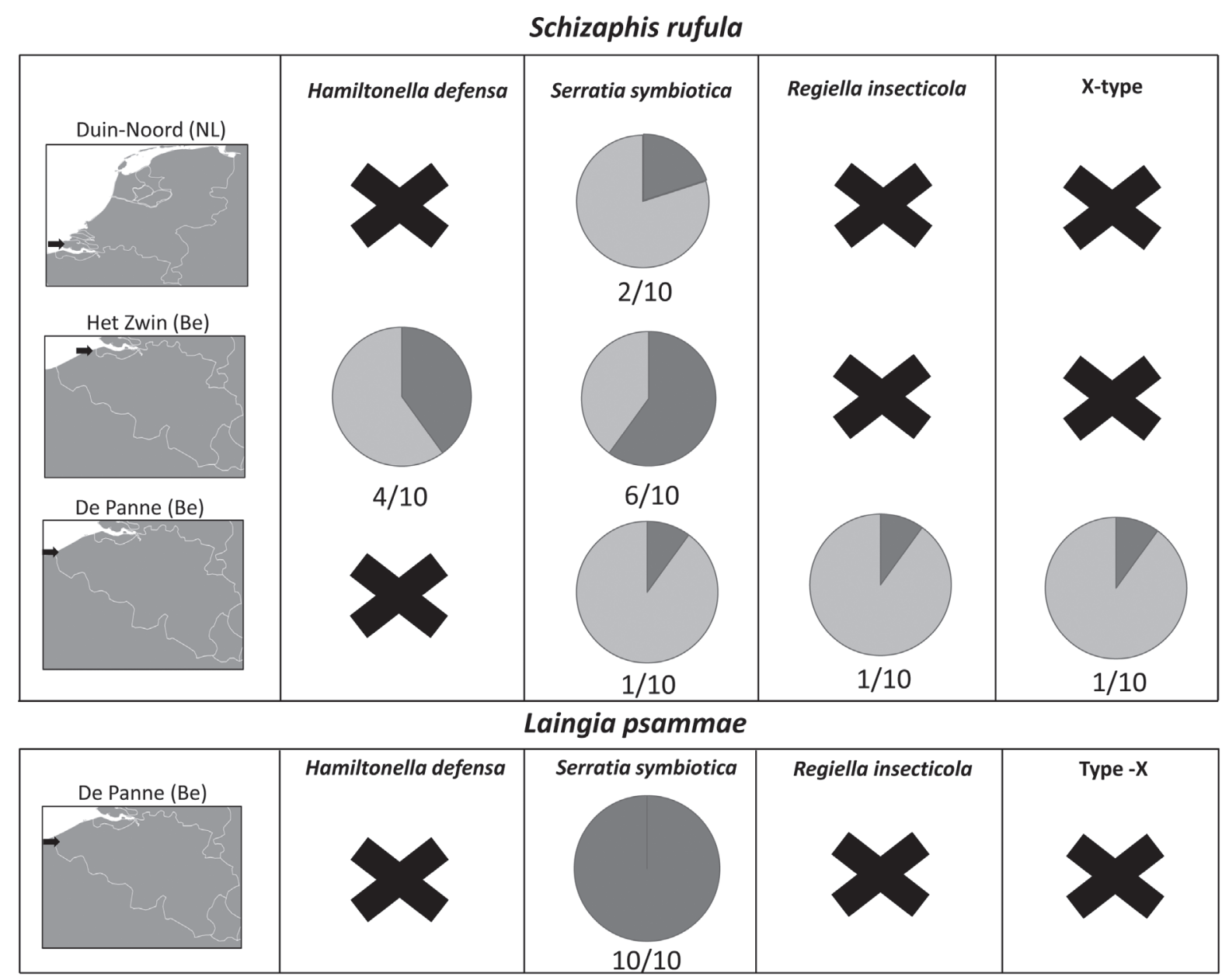

Fig 4. - Frequency of facultative endosymbionts in two species of aphids found in coastal dunes: Schizaphis rufula and Laingia psammae. 
plants, only separated a few meters, showed dissimilar endosymbiotic profiles. Moreover, the results showed that different species of dune aphids shared facultative endosymbionts. For instance, L. psammae, R. padi and S. rufula were all infected with $S$. symbiotica. Also temporal variation in the occurrence of endosymbionts cannot be excluded since different endosymbionts were detected in the samples collected in June and in October.

These findings open interesting future research avenues. For instance, $H$. defensa is an endosymbiont already reported in aphids and other sap-feeding insects as protecting its hosts from parasitoid wasps (OLIVER, 2010; NYABUGA et al., 2010; MCCLEAN et al., 2011; LUKASIK et al., 2013). As observed in the field, the sampled populations were frequently parasitized by parasitoid wasps but only a few individuals from Het Zwin revealed the presence of $H$. defensa. Since not all $H$. defensa strains are known to confer resistance to parasitoids and the effect also varies among aphid species (DEGNAN et al., 2009; VORBURGER et al., 2009) the meaning of the interaction for this Belgian aphid population needs further experimental examination. The correlation analysis did not show any relationship between $H$. defensa and the number of mummies detected in the field. However, these results should be taken with caution due to the limited number of observations and also because a lack of correlation cannot exclude causality. The same type of ideas can be put forward regarding $R$. insecticola as this endosymbiont is known to protect aphids from different natural enemies. Preliminary experimental manipulations with $R$. insecticola in other aphid species have demonstrated that it confers resistance against aphid fungal pathogens (FERRARI et al., 2004; SCARBorough et al., 2005). Nonetheless, it has also been shown that this endosymbiont protects Myzus persicae and Aphis fabae against parasitoids (VORBURGER et al., 2009).

Serratia symbiotica was consistently detected in the three species (S. rufula, R. padi, L. psammae) collected in coastal dunes from both sampling dates. Dune habitats are not only harsh for the plant community but also for the associated insects. For example, oscillations in temperature of $c a .25^{\circ} \mathrm{C}$ are common during the summer and dune sand can easily reach temperatures above $50^{\circ} \mathrm{C}$ (MAUN 2009). Besides different life history traits and behavioral adaptations to such rapid environmental changes, symbiotic relationships with facultative bacteria may ameliorate such harsh environmental conditions. The facultative endosymbiont $S$. symbiotica has been reported to be pivotal in protection against heat shocks in several species of aphids; in arid areas a relatively high proportion of aphids are found to be carrying this symbiont (HENRY et al., 2013; BRUMIN et al., 2011; BURKE et al., 2010). Whether this is the case for dune species requires further investigation. Nonetheless, it is noteworthy that the three aphids species do carry this symbiont.

A regulatory role of some endosymbionts has been reported in the literature. For instance, in the pea aphid comparison of strains with similar genetic background with or without Rickettsia showed a remarkable interaction between this endosymbiont and other endosymbiotic bacteria, including Buchnera aphidicola (SAKURAI et al., 2005). From other systems, we also know that the $\gamma$-protobacteria X-type plays a pivotal role in the regulation of resistance against parasitoid wasps during abiotic stress (GUAY et al., 2009). Whether this applies to the species included in this study is a question that needs further analysis. In this direction points the correlation of $R$. insecticola with the endosymbiont X-type and $H$. defensa with $S$. symbiotica.

Regarding the aphid species studied here, we still have very limited knowledge on the factors determining their population dynamics on dune grasses. Experimental evidence shows that population growth in S. rufula and R. padi is negatively affected by the presence of plant parasitic nematodes in grass roots (DE LA PEÑA et al., 2009; VANDEGEHUCHTE et al., 2011). Other experiments have shown that fungal endophytes are also involved in the control of aphid 
populations through belowground / aboveground plant-mediated interactions (JABER \& VIDAL 2009; DE LA PEÑA unpublished). In the field, we found significant numbers of aphid mummies, indicating that aphid control by parasitoid wasps occurs in the dunes. Preliminary research addressing the host-range of $S$. rufula has also shown that the species is able to feed on several grasses (PETTERSSON 1971), but given the differences in the composition of the endosymbiont community it would be interesting to address the question of whether aphid hostrange is influenced by these endosymbionts. Putting all these pieces together, it is clear that in order to understand the ecology of aphids on dune grasses a multitrophic perspective needs to be taken to further understand how all these players modulate each other (VANDEGEHUCHTE et al., 2013).

More and more empirical evidence reveals the pivotal role of facultative bacteria in mediating indirect interactions in insect communities through changes in plant physiology (FRAGO et al., 2013). The results of our initial assessment showed an unexpected diversity of facultative endosymbionts in dune aphids. The further study of these inconspicuous organisms in coastal dunes will provide new insights into the functioning of these ecosystems. Finally, it is important to highlight that the aphid species included in this study are not only relevant for the dune system; they offer an interesting system to address general eco-evolutionary questions regarding bacterial endosymbionts, the community in which they are embedded, and their abiotic environment.

\section{ACKNOWLEDGEMENTS}

Eduardo de la Peña has enjoyed during the course of this research a post-doctoral fellowship of the Flemish Foundation for Scientific Research (FWO, Belgium) and a Ramón y Cajal research contract (Subprograma Ramón y Cajal, Ministerio de Economía y Competitividad, Spain). Enric Frago is currently funded by Marie Curie Intra-European Fellowship within the 7th
European Community Framework Programme. The authors would like to thank Prof. Fréderick Hendrickx for his useful suggestions while preparing the manuscript and Graeme Rycyk for his suggestion regarding English usage.

\section{REFERENCES}

Benson Da, Cavanaugh M, Clark K, KarschMIZRACHI I, LIPMAN DJ, OSTELL J, SAYERS EW. (2013) GenBank. Nucleic Acids Research Jan; (D1) D36-42.

BRÖRING U. \& NIEDRINGHAUS (1989) Die epigäische Hemipterenfauna (Heteroptera, Auchenorrhyncha) der Tertiärdünen Ostfriesischer Düneninseln. - Braunschw. naturk. Schr. 3: $387-$ 398.

Brumin M, Kontsedalov S, GHAmin M. (2011) Rickettsia influences thermotolerance in the whitefly Bemisia tabaci B biotype. Insect Science 18, 57-66.

Burke G, Hiehn O, Moran N (2010) Effects of facultative symbionts and heat stress on the metabolome of pea aphids. The ISME Journal 4:242-252.

de la Peña E, Karssen G, Moens M (2007) Diversity and distribution of root lesion nematodes associated to Ammophila arenaria in Europe dunes. Nematology, 9: 881-901.

de la PeÑa E, Bonte D, Moens M (2009) Evidence of population differentiation in the dune grass Ammophila arenaria and its associated rootfeeding nematodes. Plant and Soil 324 (1-2): $307-$ 316.

DE LA PeÑa E, RodRÍGUEZ-ECHEVERRÍA S, VAN Der Putten WH, Freitas H, Moens M (2006) Mechanism of control of root-feeding nematodes by arbuscular mycorrhizal fungi in the dune grass Ammophila arenaria. New Phytologist, 169:829840.

Degnan PH, Yu Y, Sisneros N, Wing RA, Moran NA (2009) Hamiltonella defensa, genome evolution of protective bacterial endosymbiont from pathogenic ancestors. Proceedings of the National Academy of Sciences 106 (22): 90639068.

Ferrari J, DARBy AC, DANiell TJ, Godfray HCJ, Douglas AE (2004) Linking the bacterial community in pea aphids with host-plant use and 
natural enemy resistance. Ecological Entomology 29: 60-65.

FERRARI J, WeSt JA, GodFray HCJ (2011) Population genetic structure and secondary symbionts in host-associated populations of the pea aphid complex. Evolution 66(2): 375-390.

Frago E, Dicke M, GODFRAY HCJ (2012) Insect symbionts as hidden players in insect-plant interactions. Trends in Ecology \& Evolution, 27(12): 705-711.

Guay JF, Boudreault S, Michaud D, Cloutier C (2009) Impact of environmental stress on aphid clonal resistance to parasitoids: Role of Hamiltonella defensa bacterial symbiosis in association with a new facultative symbiont of the pea aphid. Journal of Insect Physiology 55: 919926.

Henry LM, Peccoud J, Simon JC, Hadfield JD, MAIDEN MJC, FERRARI J, GODFRAY HCJ (2013). Horizontally transmitted symbionts and host colonization of ecological niches. Current biology 23(17), 1713-7.

JABER LR, VIDAL S (2009) Interactions between and endophytic fungus, aphids and extrafloral nectaries: do endophytes induce extrafloralmediated defenses in Vicia faba. Functional Ecology 23(4), 707-714.

LEONARDO T E \& MONDOR EB (2006). Symbiont modifies host life history traits that affect gene flow. Proceedings of the Royal Society of London B - Biological Sciences 273: 1079-1084.

LUKASIK P, DAWID MA, FERRARI J, GODFRAY HCJ (2013) The diversity and fitness effects of infection with facultative endosymbionts in the grain aphid, Sitobion avenae. Oecologia 173: 985-996.

MAUn M (2009) The biology of coastal sand dunes. Oxford University press.

MCClean AHC, VAN Asch M, FERRARI J, GODFRAY HCJ (2011) Effects of bacterial secondary symbionts on host plant use in pea aphids. Proc. R. Soc. B, 278: 760-766.

MORAN NA, MCCUTCHEON JP, NAKABACHI A (2008) Genomics and evolution of heritable bacterial symbionts. Annual Review of Genetics. 42:16590.

Nyabuga FN, Outreman Y, Simon J, Heckel DG, WEISSER W (2010) Effects of pea aphid secondary endosymbionts on aphid resistance and development of the aphid parasitoid Aphidius ervi: a correlative study. Entomologia Experimentalis et Applicata 136: 243-253.

Oliver KM, Degnan PH, Burke GR, Moran NA (2010) Facultative symbionts in aphids and the horizontal transfer of ecological important traits. Annu. Rev. Entomol. 55:247-266.

PETTERSSON J (1971) Studies on four grass-inhabiting species of Schizaphis (Hem: Aphidoidea) II. Morphological descriptions of populations of $S$. dubia Huc., S. arrenatheri n. sp., S. rufula (Walk.) and $S$. longicaudata H.R.L. Swedish Journal of Agricultural Research I: 115-132.

SAKurai M, Koga R, Tsuchida T, Meng X, FUKATSU T (2005) Rickettsia $s$ symbiont in the pea aphid Acyrthosiphon pisum: novel cellular tropism, effect on host fitness and interaction with the essential symbiont Buchnera. Applied Environmental Microbiology 7: 4069-4075.

SCARborough CL, FerRari J, GOdFray HCJ (2005) Aphid protected from pathogen by endosymbiont. Science 310: 1781-1781.

Vandegehuchte M, De la Peña E, Bonte D (2010) Aphids on Ammophila arenaria in Belgium: first reports, phenology and host range expansion. Belgian Journal of Zoology, 140: 77-79.

VANDEgehuchte M, De LA PeÑa E, Bonte D (2010) Interactions between root and shoot herbivores of Ammophila arenaria in the laboratory do not translate into correlated abundances in the field. Oikos, 119: 1011-10.

Vandegehuchte M, De la Peña E, Bonte D (2013). Non-local genotypes of a resident grass species reduce invertebrate species richness. Insect Conservation and Diversity 5(6): 453-460.

VORBURGER C, SANDROCK C, GOUSKOV A, CASTAÑEDA L, FERrari J (2009) Genotypic variation and the role of defensive endosymbionts in an all-parthenogenetic host-parasitoid interaction. Evolution 63: 1439-50.

VORBURGer C, GEHRER L, RODRIGUEZ P (2010) A strain of the bacterial symbiont Regiella insecticola protect against insect parasitoids. Biology letters 6: 109-112.

Received: November 29th, 2013

Accepted: May 27th, 2014

Branch editor: Frederik Hendrickx 